\title{
Improving Root Health and Yield of Dry Beans in the Nebraska Panhandle with a New Technique for Reducing Soil Compaction
}

\author{
R. M. Harveson, Plant Pathologist, and J. A. Smith, Machinery Systems Engineer, University of Nebraska, Panhan- \\ dle Research and Extension Center, Scottsbluff 69361; and W. W. Stroup, Statistician, University of Nebraska, De- \\ partment of Statistics, Lincoln 68583
}

\begin{abstract}
Harveson, R. M., Smith, J. A., and Stroup, W. W. 2005. Improving root health and yield of dry beans in the Nebraska Panhandle with a new technique for reducing soil compaction. Plant Dis. 89:279-284

A field study conducted during the 2001 and 2002 growing seasons investigated the integration of fungicide applications and tillage methods for reducing root health problems in dry bean (Phaseolus vulgaris) plants by alleviating soil compaction and its potential exacerbation of root disease. Several cultural practices were combined with applications of the strobilurin fungicide azoxystrobin. Soil compaction was created artificially throughout the entire plot area. Six treatments, consisting of four tillage treatments and two combinations of tillage or applications of azoxystrobin, were tested to alleviate the compaction and enhance root health. Tillage treatments included a compacted control with no additional tillage, formation of beds approximately $10 \mathrm{~cm}$ above soil surface, zone tillage with an implement using in-row shanks, and both zone tillage and bedding combined. Fungicide treatments utilized the combination of both zone tillage and bedding with fungicide applications, and a fungicide treatment singly. Effects of compaction on plant vigor and disease development and severity were evaluated 67 and 83 days after planting in 2001 and 2002, respectively, by a visual estimation of plot vigor and by destructively sampling and making root and hypocotyl disease ratings on dry bean plants from nonharvest rows. Soil resistance and moisture were measured in plots 80 and 104 days after planting in 2001 and 2002, respectively, to estimate degree of compaction. In both years, Fusarium root rot, caused by Fusarium solani $\mathrm{f}$. sp. phaseoli, was determined to be the main root disease impacting plant health in studies. All measured variables (root disease index, plant vigor ratings, total seed yield, seed size, and soil resistance) were significantly improved by any treatment that included zone tillage prior to planting. No added advantages were observed for decreasing disease or improving root health and plant performance with the use of azoxystrobin or by planting on raised beds. This is the first study to evaluate zone tillage as a method of reducing plant stress and root disease in dry bean plants.
\end{abstract}

Nebraska is a major contributor to dry bean (Phaseolus vulgaris) production in the United States, with approximately 60,000 ha harvested in 2003. The state leads the nation in production of dry beans in the Great Northern market class, and is second in production of pinto beans, with lesser amounts of light red kidney beans also being grown.

Dry bean plants are susceptible to numerous root pathogens that may include species of Rhizoctonia, Pythium, Fusarium, Thielaviopsis, and Aphanomyces,

Corresponding author: R. M. Harveson

E-mail: rharveso@unlnotes.unl.edu

A contribution of the University of Nebraska Agricultural Research Division, Lincoln 68583. Journal series no. 14259.

This work was supported by a grant from the Anna Elliott Foundation for western Nebraska agricultural research.

Accepted for publication 14 October 2004.

DOI: 10.1094/PD-89-0279

(C) 2005 The American Phytopathological Society and several of these pathogens often occur as a disease complex $(25,27,36)$. A recently completed root disease survey found that the dry bean root disease complex in Nebraska included Fusarium yellows (caused by Fusarium oxysporum f. sp. phaseoli), in addition to several diseases caused by Rhizoctonia solani (teleomorph, Thanatephorus cucumeris) and Pythium spp. (R. M. Harveson, unpublished). The identification of $R$. solani as an important dry bean pathogen in Nebraska is particularly significant because it also has been reported as a pathogen of several common weeds (12) and sugar beet (Beta vulgaris) $(10,28,29)$, which commonly are grown in rotation with dry bean cultivars in western Nebraska.

More importantly, this survey additionally revealed that the most commonly occurring disease statewide was Fusarium root rot, caused by F. solani f. sp. phaseoli (R. M. Harveson, unpublished). This pathogen causes hypocotyl lesions and rotting of roots and crowns of many plant species within several leguminous genera, but is economically important primarily as the cause of root rot on Phaseolus spp. (5).
Fusarium root rot also occurs in most bean fields throughout the world, generally becoming apparent after two to three crops of beans are produced, and usually causes little damage unless the plants are stressed by certain environmental factors that restrict normal root growth and development $(6,8,11)$. However, under the proper environmental conditions, the disease can be severe (7) and significantly impact dry bean production. In Nebraska, yield reductions of 52 and $42 \%$ due to this disease were estimated for Great Northern beans and pinto beans, respectively (33). In Colorado, pinto bean yield losses averaged 62 and $27 \%$, with some fields as high as 89 and $66 \%$, in 1971 and 1972, respectively (19).

$R$. solani may induce a number of diseases in dry bean plants, including damping-off, stem canker, root rot, and pod rot (3). Reddish-brown, sunken lesions develop on older plant hypocotyls and often extend above the soil surface and girdle entire stems, subsequently causing stunting or plant death $(3,24)$. Mid- to late-season moisture stresses will exacerbate this problem, resulting in greater levels of damage due to disease (24).

Fusarium root rot often is aggravated by the presence of a compacted soil, because the pathogen becomes dispersed and primarily confined to the plow layer $(6,8)$. The severely restricted roots then become infected and rotted, reduced in volume, and less capable of extending into sources of water and nutrients that promote optimum growth (20). Effects of Rhizoctonia hypocotyl rot and stem canker similarly are compounded by factors (including soil compaction) that cause stress in plants, resulting in reduced root development $(3,24,36)$.

Soil compaction is a potential problem wherever mechanized crop production is practiced (1), and often is an overlooked source of stress for dry bean crops. Excess soil compaction decreases porosity, degrades soil structure, and can impede water movement and root growth $(1,7)$. Compaction can occur naturally in some soil types, or can be created from wheel traffic, tillage or planting implements, or any equipment that is used for spraying, cultivating, harvesting, or transporting (1).

Reducing compaction and dry bean root rot has been accomplished with a number of cultural practices, such as planting dry bean after wheat (Triticum aestivum) or 
alfalfa crops (Medicago sativa), and moldboard plowing or subsoiling prior to planting $(1,7,8,30,35)$. However, several disadvantages have been associated with preplant subsoiling, including loss of soil moisture and surface residue (7). Subsoiling after plant emergence also can be problematic by causing damage to developing roots and pushing bean plants out of rows, making later cultivations difficult (7).

Zone tillage is a relatively new and increasingly popular technique that offers a number of advantages over typical subsoiling or moldboard plowing operations for dry bean production. This tillage system is a regionally developed variation of strip tillage that effectively conserves soil moisture, only works in the horizontal zone where the dry bean row will be planted, tills only to the depth to alleviate any soil compaction present, and can be operated in almost any previous crop residue or soil condition (31).

The strobilurins are a newly developed class of fungicides and were first sold in 1996. Azoxystrobin (Quadris; Syngenta Crop Protection, Greensboro, NC) is active against all four major groups of plantpathogenic fungi (2), including the basidiomycete $R$. solani, and now is registered in the United States for use in dry bean for control of soilborne diseases caused by $R$. solani. However, it has no activity against $F$. solani.

This study was conducted over two seasons with the purpose of testing the integration of several cultural methods with applications of the fungicide azoxystrobin to evaluate their ability at relieving two particular stress factors (soil compaction and root diseases) commonly experienced by dry bean growers in Nebraska. Previously untested cultural practices, including zone tillage and planting on raised beds, were evaluated alone and in combination with azoxystrobin applications for their

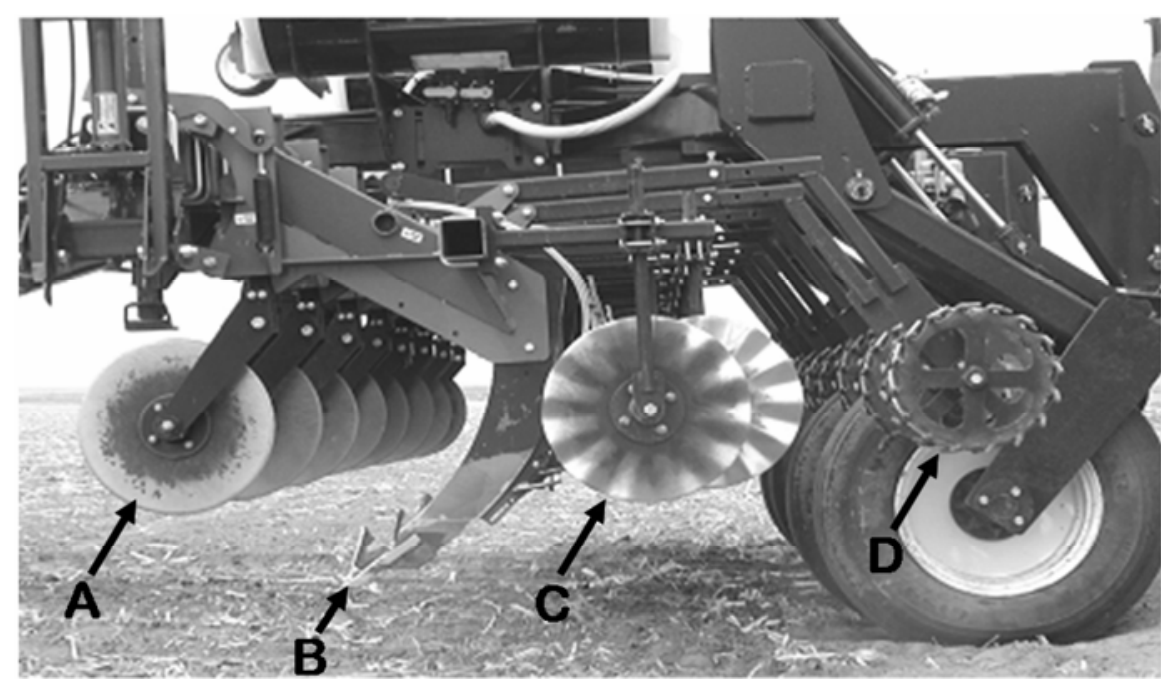

Fig. 1. Close-up view of the "Till-N-Plant" demonstrating four-feature zone tillage design. From left to right: straight coulters (A), tipped shanks set for 33-cm depth (B), wavy coulters (C), and rolling basket (D).

ability to limit root health problems in dry bean plants caused by soil compaction or root and stem disease. Zone tillage has shown promise commercially for reducing compaction and conserving soil moisture, but has not been tested experimentally as a method for disease management. Preliminary reports have been published previously $(17,18)$.

\section{MATERIALS AND METHODS}

The study was conducted in separate fields over 2 years (2001 to 2002) at the University of Nebraska's Panhandle Research and Extension Center in Scottsbluff on silt loam soils with $1 \%$ organic matter, $\mathrm{pH}$ 7.8. The plots in both years were established in fields cropped the previous year to field corn (Zea mays) and known to be infested with several different root pathogens which could affect dry bean production, including species of Fusarium and Rhizoctonia $(10,13,34)$.

Site preparation and creation of compaction. The preparation of the two fields before planting was similar both years. To ensure uniformity of compaction for the tests, the fields were moldboard plowed in late March and roller harrowed and fertilized (46-0-0) at a rate of $34 \mathrm{~kg} / \mathrm{ha}$ in late May when the top $10 \mathrm{~cm}$ of soil was very dry. Soil compaction within the field was created (12 June 2001 and 4 June 2002) by driving over the entire plot areas once with a single-axle, tandem-wheel grain truck loaded to half capacity $(2,200 \mathrm{~kg}$ front axle and $6,050 \mathrm{~kg}$ rear axle). Preplant herbicides EPTC (Eptam; Syngenta Crop Protection, Greensboro NC) and alachlor (Lasso; Monsanto, St. Louis, MO) then were applied at 2.8 and 4.7 liters/ha, respectively and incorporated in all plots with a roller harrow having tines set at a depth of $6 \mathrm{~cm}$.

After compaction was accomplished, six treatments, including four tillage and two

280 Plant Disease /Vol. 89 No. 3 fungicide treatments, arranged in a randomized block design were evaluated as potential methods for counteracting compaction and plant stress, each replicated six times. Tillage treatments consisted of (i) the compacted control with no additional tillage (other than herbicide incorporation), (ii) zone tillage utilizing the Schlagel "TillN-Plant" (Schlagel Manufacturing, Torrington, WY), (iii) formation of beds approximately $10 \mathrm{~cm}$ above compacted soil surface, and (iv) both zone tillage and bedding. The "Till-N-Plant" implement used in-row shanks set at a depth of $33 \mathrm{~cm}$, preceded by a pair of straight coulters, followed by a pair of wavy coulters to close shank traces, and a trailing rolling basket-type device to firm and level soil surface in the row to accommodate a planter (31) (Fig. 1).

Following completion of tillage treatments, all plots in both years were planted in mid-June, (15 and 10 June in 2001 and 2002, respectively) with the Great Northern cv. Beryl at a population of 170,000 seed/ha and a depth of $5 \mathrm{~cm}$. Plots consisted of six rows, each $15 \mathrm{~m}$ long on 56$\mathrm{cm}$ centers. After emergence, plots were cultivated for weed control between rows twice, furrowed, and irrigated as needed throughout each season.

Fungicide applications were made twice each year, at 25 and 59 days after planting in 2001, and 31 and 65 days after planting in 2002, at a rate of 0.93 liters/ha using a backpack sprayer with a three-row boom. Fungicide treatments included (i) two applications of the strobilurin fungicide azoxystrobin by itself with no additional treatment and (ii) two applications made in plots treated with both zone tillage and bedding. Sprays were directed in a band over the plants using 13 liters of water per treatment at a pressure of $138 \mathrm{kPa}$ to insure thorough coverage of lower stems and soil surface surrounding plant bases.

Data collection. Disease evaluations were recorded 67 and 83 days after planting in 2001 and 2002, respectively. Mortality counts were taken from the middle two (harvest) rows of each six-row plot. In addition, 10 plants were removed at $1-\mathrm{m}$ intervals from an adjacent nonharvest row from each plot, and assigned a disease severity rating ( 0 to 4 ) as follows: $0=$ no disease; 1 = individual, localized lesions on stems or hypocotyls or up to $25 \%$ of root surface necrotic; $2=$ multiple stem or hypocotyl lesions coalescing or 26 to $50 \%$ of root surface necrotic, but no rotting of internal pith tissues; $3=51$ to $75 \%$ of stem or root system rotted, including internal pith tissues; and $4=>75 \%$ of stem or root system rotted. A disease index (DI) previously used for similar root diseases of sugar beet $(14,16)$ then was calculated from the severity rating using the equation $\mathrm{DI}=[\mathrm{DR} 1+(\mathrm{DR} 2 \times 2)+(\mathrm{DR} 3 \times 3)+$ $(\mathrm{DR} 4 \times 4)] /(\Sigma$ DR0 -4$)$, where DR1 = number of roots rated $1, \mathrm{DR} 2=$ number of 
roots rated 2, DR3 = number of roots rated 3 , and DR4 $=$ number of roots rated 4 .

On the same day that the root disease ratings were made, plots were rated (1 to 5) for growth and general vigor of dry bean plants as follows: 1 = rows completely closed with plants touching those in adjacent plots; 2 = rows 75 to $90 \%$ closed; $3=$ rows 50 to $75 \%$ closed, but plants not severely stunted; 4 = rows approximately $50 \%$ closed, with plants becoming noticeably stunted; and $5=$ rows less than $50 \%$ closed and plants severely stunted (Fig. 2).

After performing the root disease ratings each year, a subsample of the infected plants (two plants/plot) was retained and evaluated in the laboratory to further confirm identity of pathogens. Two millimeter-sized pieces of crowns and lower hypocotyls from infected plants were surface disinfested for 2 to $3 \mathrm{~min}$ in $90 \% \mathrm{ETOH}$, a $10 \%$ dilution of commercial bleach $(5.25 \%$ sodium hypochlorite), and distilled water (15), followed by blotting dry with paper towels. Four tissue pieces per plant then were cultured on one-half potato dextrose agar amended with streptomycin sulfate at $300 \mathrm{ppm}$ (15) in the dark in an incubator held at $27^{\circ} \mathrm{C}$. $R$. solani colonies were identified by typical morphological characteristics (32). Resulting Fusarium isolates were single-spored and identified to species by standard methods on carnation leaf agar (CLA; 4).

Soil compaction was evaluated physically within each plot in each year by measuring resistance with a cone penetrometer (ELE International, Inc., Lake Bluff, IL), and estimating soil moisture concentrations in September (80 and 104 days after planting for 2001 and 2002, respectively). Two measurements were taken per plot from the center of each of the two middle harvest rows at a depth of $30 \mathrm{~cm}$. Soil samples were taken at this time from the upper $10 \mathrm{~cm}$ from the same plots with a soil probe (approximately $235 \mathrm{ml}$ by volume) and percent moisture was determined on a gravimetric basis. These measurements then were averaged to estimate soil moisture throughout the entire field.

Plots were harvested on 18 and 26 September in 2001 and 2002, respectively. Harvest was accomplished by removing all plants by hand from the center $6 \mathrm{~m}$ of the middle two $15-\mathrm{m}$ rows of each plot and air drying for 2 weeks in cloth bags. Total seed yield and seed size (weight of 200 seed) were obtained after threshing dried pods in a stationary dry bean thresher (Bill's Welding Co., Pullman, WA).

Data analysis. Data were analyzed using mixed model methods for randomized complete block designs as described by Littell et al. (22). Computations were implemented using SAS PROC MIXED (SAS Institute, Cary, NC). Analysis was combined over the 2 years of the study after verifying the assumption of homoge- neity of variance between tests in each year. In the combined analysis, the hypothesis of no treatment-test interactions was first tested to determine whether treatment differences were consistent over the two tests. Where appropriate (i.e., where treatment-test interactions were negligible), treatment means were compared. Differences among treatment means then were partitioned and contrasted with dependent variables as follows: (i) effect of zone tillage alone, (ii) effect of bedding alone, (iii) zone tillage-bedding interaction, (iv) all zone tillage treatments versus all treatments without zone tillage, (v) differences between all treatments using zone tillage, and (vi) differences between all treatments without zone tillage.

\section{RESULTS}

Results from the 2002 study were substantially different than results in 2001 in several respects. One of most striking differences between studies involved plant mortality within plots. During 2001, the number of dead plants recorded in plots lacking zone tillage averaged 37.8 and these values were significantly different $(P$ $=0.0001$ ) from those from plots treated with zone tillage (average 7.9 dead plants). No dead plants were observed from any plots during 2002.

The climatic conditions also were different between years and studies, with 2002 being warmer and much drier than 2001 . For example, mean daily temperatures in 2002 were approximately $2^{\circ} \mathrm{C}$ higher than those in 2001, and rainfall received in Scottsbluff during 2002 totaled only 20 $\mathrm{cm}$, which is approximately one-half that of 2001 and the historically observed rainfall average. The drier conditions experithe average late-season soil moisture readings across the entire study, calculated to be $16.8 \%$ in 2001 and $12.9 \%$ in 2002 . enced during 2002 also were reflected in

Despite the differences between years (climate and plant mortality), the two studies yielded consistent results with respect to treatment differences for all measured variables, including disease index, vigor ratings, total seed yield and seed size, and soil resistance. The variance between repeated studies was homogenous, and no non-negligible treatment-test interactions were observed; therefore, all data analysis was combined over both years and inference was focused on treatment differences averaged over both tests. The predominant root disease identified in the plots for both years of this study was Fusarium root rot, caused by $F$. solani f. sp. phaseoli. F. solani was isolated from 83\% (80 of 96 in 2001) and 77\% (74 of 96 in 2002) of the subsample of plants collected after being rated for disease severity. Less than $10 \%$ of the cultured dry bean plants yielded $R$. solani (7 and 4\% for 2001 and 2002, respectively). Early symptoms of Fusarium root rot consisted of small, reddish-brown lesions and streaks on hypocotyls and taproots. As disease progressed, the lesions coalesced to form larger necrotic areas that were restricted primarily to the cortical tissues $(7,11)$.

Results of contrast analysis illustrating the statistically significant differences attributable to zone tillage effects, and lack of difference among those treatments without zone tillage. The soil resistance values obtained, combined with plant response (disease and vigor ratings; Table 1), indicate that compacted conditions were successfully produced. Those treatments lacking zone tillage had significantly higher soil resistance values, higher disease ratings, and poorer vigor ratings than those including it (Table 1). Individual plants collected from the compacted control treatment were severely stunted with a poorly developed root system, compared with those taken from a zone tillage-

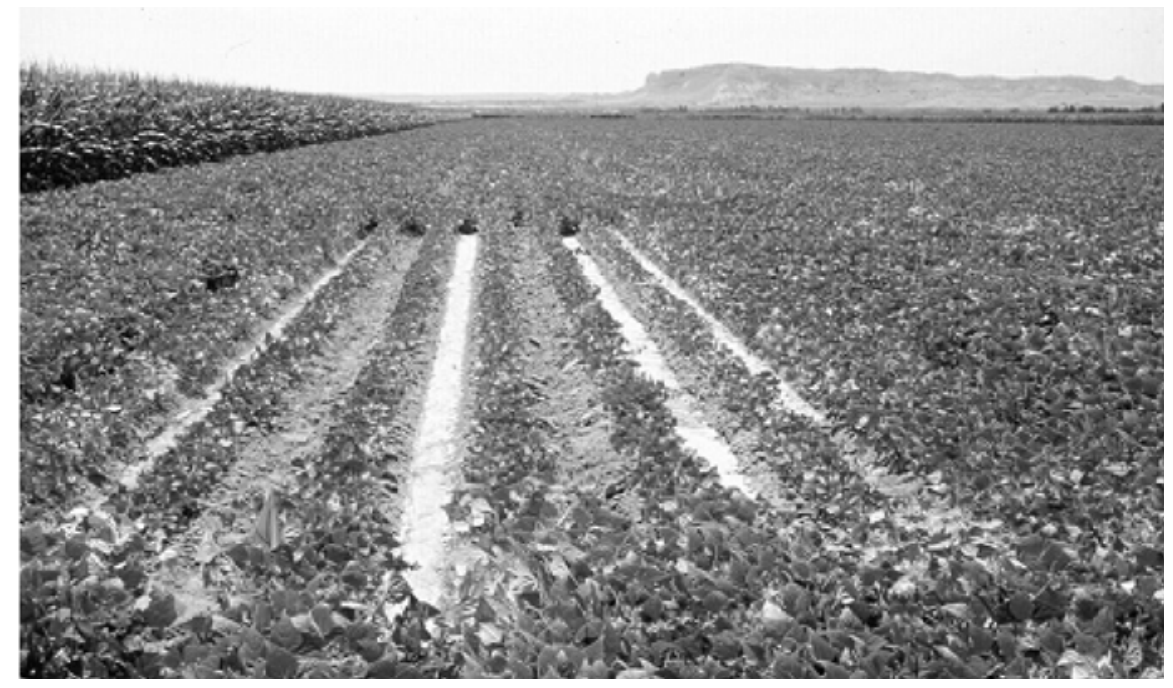

Fig. 2. Effects of compaction on dry bean plant growth at approximately 70 days after planting. Represents a 5 on the vigor rating scale ( 1 to 5 ), with 5 being most severe. Note stunting and failure of plants to close rows $(<50 \%)$ compared with surrounding plots. 
treated plot. These effects on plant growth were evident in the field within 2 to 3 weeks of emergence, and affected plants remained stunted throughout the season (Fig. 3).

Dry bean yield in zone-tilled plots was significantly higher than yield where zone tillage was not used (Table 1). Across treatments, seed yields from zone tillage treatments were increased by an average of $79 \%$ and seed size was increased $6 \%$ compared with the compacted control. Zonetilled treatments also significantly reduced soil resistance by $76 \%$ compared with compacted control.

No significant yield improvements or reductions in plant stress were observed from applications of azoxystrobin to the base of the plants or planting dry bean on raised beds. These treatments resulted in disease indices, vigor ratings, and yields that were not significantly different than those from the compacted control (Table 1). Furthermore, no synergistic effects were significant with the combination treatments.

\section{DISCUSSION}

One of the more common stresses that a dry bean crop can experience in western Nebraska is the unintentional creation of soil compaction by mechanical operations during the production of previous crops. The traditional rotation sequence for irrigated crops in the Nebraska Panhandle, particularly the North Platte Valley, consists of corn followed by dry bean followed by sugar beet (12). Several variations of this system have been attempted, with alfalfa and winter wheat being transitioned into this sequence in the place of sugar beet. It has been long observed that dry bean following sugar beet crops often do not yield well; thus, dry bean crops generally precede sugar beet in this region. The reasons for these observations are uncertain, but could be due to pathogens common to both crops, such as $R$. solani $(10,28,29)$, or excessive soil compaction that often results from harvesting operations after cropping sugar beet (20).

We tried to create a reasonable level of compaction that would simulate field con-

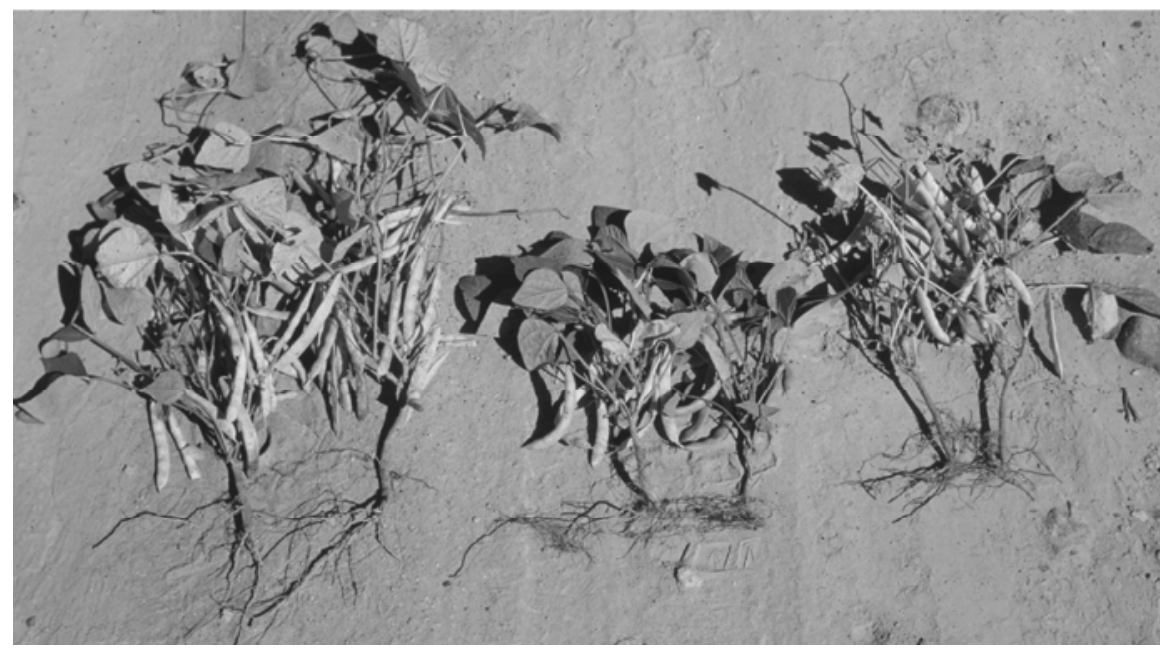

Fig. 3. Effects of compaction and root stress on dry bean plants near harvest (approximately 90 days after planting). From left to right, plants removed from plots treated with: zone tillage, compacted control, and bedding alone, each representing an overall plot vigor rating of 1.0 to $1.5,4.0$ to 4.5 , and 3.5 to 4.0 , respectively. Note differences in size of plants, number and size of seed pods produced, and degree of root inhibition of plants from non-zone-tillage treatments.

Table 1. Least square means results for treatments evaluated as methods for alleviating soil compaction, improving yield parameters, and reducing root disease effects in dry-edible bean crops (2001-02)

\begin{tabular}{|c|c|c|c|c|c|}
\hline Treatment $^{\mathrm{a}}$ & $\mathbf{D I}^{\mathbf{b}}$ & $\mathbf{V R}^{\mathrm{c}}$ & $Y^{d}$ & $\operatorname{Size}^{\mathrm{e}}$ & Resist $^{\mathrm{f}}$ \\
\hline Control & 3.43 & 4.04 & $1,499.9$ & 52.2 & 575.7 \\
\hline Zone tillage & 1.44 & 1.12 & $2,645.0$ & 54.9 & 141.8 \\
\hline Bedding & 3.14 & 4.17 & $1,474.1$ & 51.9 & 497.6 \\
\hline Tillage + bedding & 1.47 & 1.17 & $2,661.3$ & 55.4 & 150.9 \\
\hline Fungicide & 3.40 & 4.17 & $1,472.7$ & 50.8 & 590.7 \\
\hline Tillage + bedding + fungicide & 1.45 & 1.13 & $2,749.6$ & 56.3 & 112.7 \\
\hline Standard error of difference & 0.13 & 0.13 & 101.1 & 0.90 & 26.29 \\
\hline Contrast & \multicolumn{5}{|c|}{ Tests of contrasts $(F \text { value, } P>F)^{\mathrm{g}}$} \\
\hline Zone effect & $197.39(0.0001)$ & $479.49(0.0001)$ & $133.18(0.0001)$ & $11.97(0.0011)$ & $220.32(0.0001)$ \\
\hline Bed effect & $0.94(0.3359)$ & $0.38(0.5402)$ & $1.08(0.3048)$ & $0.00(0.9488)$ & $1.73(0.1948)$ \\
\hline Zone $\times$ bed interaction & $1.51(0.2252)$ & $0.10(0.7591)$ & $1.43(0.2366)$ & $0.18(0.6752)$ & $2.75(0.1033)$ \\
\hline All zone vs. all without & $309.94(0.0001)$ & $732.80(0.0001)$ & $230.04(0.0001)$ & $28.12(0.0001)$ & $381.83(0.0001)$ \\
\hline Among treatments with zones & $0.02(0.9813)$ & $0.03(0.9688)$ & $0.31(0.7346)$ & $0.59(0.5584)$ & $0.58(0.5657)$ \\
\hline Among treatments without zones & $1.47(0.2389)$ & $0.29(0.7530)$ & $2.08(0.1360)$ & $0.64(0.5319)$ & $3.62(0.0341)$ \\
\hline
\end{tabular}

${ }^{\text {a }}$ Control = compacted control with no additional tillage; Tillage = zone tillage with a Schlegel Manufacturing "Till-N-Plant" implement which used in-row shanks set at a depth of $33 \mathrm{~cm}$; Bedding = formation of beds $10 \mathrm{~cm}$ above soil surface; Fungic $=$ azoxystrobin applied twice, 25 and 59 days after planting (DAP) in 2001 and 31 and 65 DAP in 2002, with no additional tillage (all fungicides were applied at a rate of 0.93 1/ha); Zone = influence of zone tillage treatments alone; bed effect $=$ influence of bedding treatments alone; zone $\times$ bed $=$ zone-bedding interaction, influence of zone tillage and bedding treatments combined; With vs. without $=$ influence of all zone tillage treatments compared with all those without zone tillage; Among with = differences among all treatments, including zone tillage; Among without $=$ differences among all treatments, not including zone tillage.

${ }^{\mathrm{b}} \mathrm{DI}=$ disease index based on a disease severity rating (DR) of 0 to 4 , where $0=$ no disease; $1=$ individual, localized lesions on stems or hypocotyls or up to $25 \%$ of root surface necrotic; 2 = multiple stem or hypocotyl lesions coalescing or 26 to $50 \%$ of root surface necrotic, but no rotting of internal pith tissues; $3=51$ to $75 \%$ of stem or root system rotted, including internal pith tissues; and $4=>75 \%$ of stem or root system rotted. DI is calculated by the equation DI $=[\mathrm{DR} 1+(\mathrm{DR} 2 \times 2)+(\mathrm{DR} 3 \times 3)+(\mathrm{DR} 4 \times 4)] /(\Sigma \mathrm{DR} 0-4)$, where DR1 $=$ number of roots rated $1, \mathrm{DR} 2=$ number of roots rated $2, \mathrm{DR} 3=$ number of roots rated 3 , and DR4 = number of roots rated 4 .

${ }^{c} \mathrm{VR}=$ overall plant growth and vigor rating for each plot ( 1 to 5 ), with 5 being plants most severely affected. $1=$ rows completely closed, with plants touching those in adjacent plots; 2 = rows 75 to $90 \%$ closed; $3=$ rows 50 to $75 \%$ closed, but plants not severely stunted; $4=$ rows approximately $50 \%$ closed, with plants becoming moderately stunted; and $5=$ rows less than $50 \%$ closed and plants severely stunted and chlorotic.

${ }^{\mathrm{d}}$ Total seed weight $(\mathrm{g})$ harvested from plants in two middle rows $(6 \mathrm{~m})$ of six-row plots.

e Weight of 200 seed (g).

${ }^{\mathrm{f}}$ Average of two resistance measurements $(\mathrm{kPa})$ obtained in early September from a cone penetrometer at a depth of $30 \mathrm{~cm}$. Soil moisture (upper $10 \mathrm{~cm}$ ) from plots was estimated by gravimetric means and averaged across the entire plot areas (16.8 and 12.9\% for 2001 and 2002, respectively).

$\mathrm{g}$ Results for tests of contrasts (denominator degrees of freedom $=50$ for all contrasts). 
ditions following a crop of corn and all traffic associated with a typical harvest in western Nebraska. We were able to successfully create measurable compaction (Table 1), and the tire-to-soil pressure creating compaction was less than what would be expected from a fully loaded grain truck or cart in a grower's field.

Sublethal root diseases also may provide another unexpected source of stress to dry bean plants, resulting in considerably reduced growth and yield of plants $(3,36)$. For example, stressed plants growing in the presence of $F$. solani f. sp. phaseoli often are predisposed to damage and yield loss by this pathogen (7). If dry bean plants are exposed to soil conditions conducive for optimal plant growth, they seldom are adversely affected, even if grown in the presence of $F$. solani (20). R. solani also can induce similar problems, often causing an increase in stem rot in mid- to late season in plants stressed by dry or otherwise non-optimal conditions (24).

It was not surprising to see the high incidence of Fusarium root rot in the trials, because these fields had a previous history with this disease and its causal agent was determined to be the most widely identified and distributed root pathogen from an extensive survey of Nebraska dry bean production fields (R. M. Harveson, unpublished). It was, however, unexpected to encounter the low levels of Rhizoctonia hypocotyl and stem rot. We anticipated some degree of hypocotyl and stem rot disease due to $R$. solani for several reasons. Disease due to Rhizoctonia spp. has been shown to be more severe in situations where seed were planted at depths of $4 \mathrm{~cm}$ than at $1 \mathrm{~cm}$ (26), and we planted at a depth of $5 \mathrm{~cm}$ in an attempt take advantage of soil moisture deeper in the profile to facilitate seedling emergence. Second, both sugar beet and dry bean are reported to be susceptible to $R$. solani isolates belonging to anastomosis groups (AGs) 2 and $4(10,23,29)$, and both of these fields had a previous history of Rhizoctonia root rot problems in sugar beet production $(13,34)$.

We chose to evaluate azoxystrobin (Quadris) applications because it was a new and promising product for $R$. solani at the time this study was initiated (2), and because it had effectively reduced Rhizoctonia root and crown rot in sugar beet plants grown in these same fields (34). The known presence of $R$. solani in these fields and its tendency to induce stem lesions at or above the soil surface as plants become stressed in midseason $(3,24,36)$ created an opportunity for testing this product on dry bean. We hypothesized that, if the stem rot phase of the disease was removed as a source of stress from the field using azoxystrobin, then perhaps the cultural practices might help to reduce effects of $F$. solani (which is not sensitive to azoxystrobin). Not surprisingly, the fungicide treatments by themselves were inconsequential, likely because of the low levels of Rhizoctonia stem rot observed in plots throughout the study.

Treatment with azoxystrobin provided no added advantages when combined with zone tillage, and treatments including zone tillage with bedding or fungicides were no better than zone tillage treatments individually (Table 1 ). Therefore, it was concluded that zone tillage was the critical factor for lowering soil resistance (reducing compaction), resulting in less stress and root disease (due primarily to Fusarium root rot) and, ultimately, better yield results.

Although more difficult to quantify, failure to alleviate the stress factors also potentially can result in other production problems. These include higher weed populations in compacted plots due to poor dry bean plant growth and competition, and a delay in maturity and plant dry down. Harvest was delayed approximately 1 week in this study compared with the area average due to the slower maturation of plants in compacted, non-zone-tillage plots. Delaying harvest often can be problematic in this region because an early freeze in mid-September easily could damage immature pods, resulting in lowered seed quality, which would further affect a grower's profitability.

Various tillage operations have been shown to effectively alleviate soil compaction which otherwise could lead to or exacerbate existing root disease problems in dry bean $(1,6,7)$. Moldboard plowing reduced root disease from Pythium spp., Rhizoctonia spp., and $F$. solani $(21,35)$ and improved yields in fall-planted snap bean compared with disking or subsoiling (35). Deep subsoiling or loosening soil with chisels is another successfully employed method for reducing compaction both in the presence (6-8) and absence (9) of root rot pressure.

However, these tillage systems still have major disadvantages for dry bean production. For example, moldboard plowing normally requires two or more secondary tillage operations to prepare the seedbed and incorporate herbicides. These operations cause critical loss of soil moisture and reintroduce soil compaction under the multiple tractor tire tracks. Subsoiling or ripping requires high horsepower input and necessitates the same series of secondary tillage operations as does moldboard plowing to prepare for the planting operation (31).

Zone tillage eliminates or minimizes the disadvantages associated with broadcast subsoling and moldboard plowing. Zone tillage currently is being used on an estimated 70,000 ha of row crops annually in the Central High Plains and has become a popular tillage system for dry bean. It provides tillage only in a narrow width where the row will be planted, and only to the depth to alleviate any soil compaction present, resulting in a soil zone ideal for dry bean root development. No secondary operations are necessary, creating a controlled traffic system and conserving soil moisture and surface residue (31).

The use of zone tillage with the new Schlagel "Till-N-Plant" implement provided a new, economical technique that effectively created an ideal seed bed while simultaneously alleviating root stress and lowering disease incidence and severity by helping to lessen soil compaction. In fact, the use of zone tillage resulted in a yield increase of in excess of $75 \%$ compared with the control (Table 1). Using a conservative estimate of $\$ 0.45 / \mathrm{kg}$ and 2,240 $\mathrm{kg} / \mathrm{ha}$, zone tillage would have increased a grower's gross income by $\$ 750 /$ ha under the conditions of this test.

Normal tillage practices for preparing land for bean production in this region include disking twice and moldboard plowing, followed by roller harrowing twice before planting. The "Till-N-Plant" improves efficiency in this system by mounting the planter on the rear of the zone tillage implement, creating a one-pass tillage-planting system, including tillage, fertilizer application, herbicide application and incorporation, and planting (31). This is the first study to evaluate zone tillage as a tool for reducing root health problems in dry bean crops by minimizing plant stress.

\section{ACKNOWLEDGMENTS}

We thank S. Blehm, C. Carlson, D. Gatch, and K. Nielsen for technical assistance during the course of this study; H. Schwartz, J. Watkins, J. Chaky, D. Hershman, and two anonymous reviewers for critical review of the manuscript; and G. Hein for statistical advice and consultation.

\section{LITERATURE CITED}

1. Allmaras, R. R., Kraft, J. M., and Miller, D. E. 1988. Effects of soil compaction and incorporated crop residue on root health. Annu. Rev. Phytopathol. 26:219-243.

2. Bartlett, D. W., Clough, J. M., Godwin, J. R., Hall, A. A., Hamer, M., and Parr-Dobrzanski, B. 2002. The strobilurin fungicides. Pest Manage. Sci. 58:649-662.

3. Bolkan, H. A. 1980. Root rots. Pages $67-100$ in: Bean Production Problems in the Tropics. H. F. Schwartz and G. E. Galvez, eds. Centro Internacional de Agricultura Tropical, Cali, Columbia.

4. Burgess, L., W., Summerell, B. A., Bullock, S., Gott, K. P., and Backhouse, D. 1994. Laboratory Manual for Fusarium Research, 3rd ed. University of Sydney, Australia.

5. Burke, D. W., and Hall, R. 1991. Fusarium root rot. Pages 9-10 in: Compendium of Bean Diseases. American Phytopathology Society Press, St. Paul, MN.

6. Burke, D. W., Holmes, L. D., and Barker, A. W. 1972. Distribution of Fusarium solani f. sp. phaseoli and bean roots in relation to tillage and soil compaction. Phytopathology 62:550-554.

7. Burke, D. W., and Miller, D. E. 1983. Control of Fusarium root rot with resistant beans and cultural management. Plant Dis. 67:13121317.

8. Burke, D. W., Miller, D. E., Holmes, L. D., and Barker, A. W. 1972. Counteracting bean root rot by loosening the soil. Phytopathology 62:306-309. 
9. Croissant, R. L., Schwartz, H. F., and Ayers, P. D. 1991. Soil compaction and tillage effects on dry bean yields. J. Prod. Agric. 4:461-464.

10. Engelkes, C. A., and Windels, C. E. 1996. Susceptibility of sugar beet and beans to Rhizoctonia solani AG-2-2 IIIB and AG-2-2 IV. Plant Dis. 80:1413-1417.

11. Hall, R. 1996. Inoculum dynamics of Fusarium solani $\mathrm{f}$. sp. phaseoli and management of Fusarium root rot of bean. Pages 279-310 in: Principles and Practice of Managing Soilborne Plant Pathogens. R. Hall, ed. American Phytopathology Society Press, St. Paul, MN.

12. Harveson, R. M. 2003. Common weeds serving as alternate hosts for pathogens of dryedible beans and sugar beets in the Nebraska Panhandle (Abstr). Phytopathology 93:S34.

13. Harveson, R. M., Hein, G. L., Smith, J. A., Wilson, R. G., and Yonts, C. D. 2002. An integrated approach to cultivar evaluation and selection for improving sugar beet profitability: a successful case study for the central high plains. Plant Dis. 86:192-204.

14. Harveson, R. M., and Rush, C. M. 1994. Evaluation of fumigation and rhizomaniatolerant cultivars for control of a disease complex of sugar beets. Plant Dis. 78:1197-1202.

15. Harveson, R. M., and Rush, C. M. 1997. Genetic variation among Fusarium oxysporum isolates from sugar beet as determined by vegetative compatibility. Plant Dis. 81:85-88.

16. Harveson, R. M., and Rush, C. M. 2002. The influence of irrigation frequency and cultivar blends on the severity of multiple root diseases in sugar beets. Plant Dis. 86:901-908

17. Harveson, R. M., Smith, J. A., Blehm, E. S., and Gatch, R. E. 2002. Effects of cultural practices on alleviation of root disease problems caused by soil compaction in dry-edible beans. Biol. Cult. Tests Control Plant Dis. Rep. No. 17:F02.

18. Harveson, R, M. Smith, J. A. Blehm, E. S., and Gatch, R. E. 2002. Reducing root disease prob- lems in dry beans by new methods aimed at alleviating soil compaction (Abstr). Phytopathology 92:S35.

19. Keenan, J. G., Moore, H. D., Oshima, N., and Jenkins, L. E. 1974. Effect of bean root rot on dryland pinto bean production in southwestern Colorado. Plant Dis. Rep. 58:890-892.

20. Kraft, J. M., Burke, D. W., and Haglund, W. A. 1981. Fusarium diseases of beans, peas, and lentils. Pages 142-156 in: Fusarium: Diseases, Biology, and Taxonomy. P. E. Nelson, T. A. Tousson, and R. J. Cook, eds. The Pennsylvania State University Press, University Park.

21. Lewis, J. A., Lumsden, R. D., Papavizas, G. C., and Kantzes, J. G. 1983. Integrated control of snap bean diseases caused by Pythium spp. and Rhizoctonia solani. Plant Dis. 67:12411244.

22. Littell, R. C., Stroup, W. W., and Freund, R. J. 2002. SAS Systems for Linear Models, 4th ed. SAS Institute, Inc., Cary, NC.

23. Nelson, B., Helms, T., Christianson, T., and Kural, I. 1996. Characterization and pathogenicity of Rhizoctonia from soybean. Plant Dis. 80:74-80.

24. Ontario Ministry of Agriculture, Food, and Rural Affairs. 2002. Dry edible beans. Pages 215-230 in: Agronomy Guide for Field Crops, Publication 811. T. Baute, A. Hayes, I. McDonald, and K. Reid, eds. Queens' Printer for Ontario, Toronto, Canada.

25. Pfender, W. F. 1991. Pythium diseases. Pages 11-12 in: Compendium of Bean Diseases. R. Hall, ed. American Phytopathology Society Press, St. Paul, MN.

26. Phillips, A. J. L. 1989. Relationship of Rhizoctonia solani inoculum density to incidence of hypocotyl rot and damping-off in dry beans. Can. J. Microbiol. 35:1132-1140.

27. Pieczarka, D. J., and Abawi, G. S. 1978. Effect of interaction between Fusarium, Pythium, and Rhizoctonia on severity of bean root rot. Phy- topathology 68:403-408.

28. Ruppel, E. G. 1985. Susceptibility of rotation crops to a root rot isolate of Rhizoctonia solani from sugar beet and survival of the pathogen in crop residues. Plant Dis. 69:871-873.

29. Rush, C. M., Carling, D. E., Harveson, R. M. and Mathieson, J. T. 1994. Prevalence and pathogenicity of anastomosis groups of Rhizoctonia solani from wheat and sugar beet in Texas. Plant Dis. 78:349-352.

30. Silbernagel, M. J., and Mills. L. J. 1990. Genetic and cultural control of Fusarium root rot in bush snap beans. Plant Dis. 74:61-64.

31. Smith, J. A., and Pearson, C. H. 1996. Tillage practices. Pages 27-31 in: Dry Bean Production and Pest Management. Regional Bull. 562A. H. F. Schwartz, M. A. Brick D. S. Nuland, and Gary D. Franc, eds. Central High Plains Dry Bean and Beet Group, Cooperative Extension Research Center, Ft. Collins, CO.

32. Sneh, B., Burpee, L., and Ogoshi, A. 1991. Identification of Rhizoctonia Species. American Phytopathological Society Press, St. Paul, $\mathrm{MN}$.

33. Steadman, J. R., Kerr, E. D., and Mumm, R. F. 1975. Root rot of bean in Nebraska: primary pathogen and yield loss appraisal. Plant Dis. Rep. 59:305-308

34. Stump, W. L., Franc, G. D., Harveson, R. M., and Wilson, R. G. 2004. Azoxystrobin fungicide timing for Rhizoctonia root and crown rot suppression in sugar beet. J. Sugar Beet Res. 41:17-37

35. Sumner, D. R., Smittle, D. A., Threadgill, E. D., Johnson, A. W., and Chalfant, R. B. 1986. Interactions of tillage and soil fertility with root diseases in snap bean and lima bean in irrigated multiple-cropping systems. Plant Dis. 70:730-735.

36. Zaumeyer, W. J., and Thomas, H. R. 1957. A monographic study of bean diseases and methods for their control. U. S. Dep. Agric. Agric. Tech. Bull. No. 868. 